\title{
Using SPRT+ to Reduce Measure Time on Student Learning Efficiency by Pre-defined Student's Confidence Indicator
}

\author{
http://dx.doi.org/10.3991/ijet.v9i3.3317 \\ Chien-Hung Lai, Tsung-Po Lee, Bin-Shyan Jong, Yen-The Hsia \\ Chung Yuan Christian University, Taoyuan, Taiwan
}

\begin{abstract}
In traditional teaching method in course, teachers usually used test to measure students learning efficiency, but we doing lots of test that may lower student learning motivation, so our research main purpose is how to reduce the time in test that student take and measure student's learning efficiency precisely. Some researcher combine test question with confidence indicator to make student assess their confidence about the answer and get reflection so that student can think deep about the course. Another researcher point out we can use mastery of the course to reduce test time student took. No matter to use confidence indicator or mastery of the course to reduce the test time, there is no research on both of them, so our research combine sequential probability ratio test(SPRT) and confidence indicator called SPRT+ to achieve real-time assessing student's learning efficiency. Because of students assess their own learning confidence may not be very accuracy. In our research, we pre-defined student's confidence indicator base on student's mid-term score and let student finish the test, after the test we discuss if we let student finish the same test by choice their own confidence indicator, can pre-defined student's confidence indicator make the same result in measure student's learning efficiency and reduce the test time ? Result shows that we can use SPRT+(pre-defined student's confidence indicator or not) to measure student's learning efficiency and reduce the test time.
\end{abstract}

Index Terms-Learning efficiency, confidence indicator, mastery.

\section{INTRODUCTION}

In traditional teaching method in course, teacher usually use exam to measure student's learning efficiency, when a exam contain lot of concepts that make teacher hard to improve student's learning efficiency, we can't give student what they want to know, so some researcher provide using concept to measure student's learning efficiency[1][2], that lead to another problem, if we let student take lots of test, it will lower student's learning motivation which make us hard to measure student's learning efficiency. In our experiment, we use Operating System as our experiment course because Operating System contain many important concepts student must have to take lots of time on learning and doing test, so our research's key point is to reduce test time and measure student's learning efficiency precisely.

According to above, we use computer technology to do our experiment, Computer-Based-Instruction is common use in nowadays course [3][4]. For example, computer can deal huge data, so we can analysis data more easily, many research started to explore the computer application on exam and teaching in teaching technology[5],our experiment mean purpose is use confidence indicator and mastery of the course to create a new measure way that can reduce test time student took and get student's learning efficiency precisely, and use student's mid-term score as their confidence indicator compare with pre-test which student choice their confidence indicator by their own.

\section{RELATED WORK}

\section{A. Sequential Probability Ratio Test}

SPRT is used on measure student's learning mastery of the course in every teaching domain[6], it's main purpose is to measure student's grade level precisely, Abraham Wald according to Bayesian Algorithm develop SPRT decide model[7], equation like :

$$
\mathrm{PR}=\frac{\operatorname{Pom} \times \operatorname{Pm}^{\mathrm{r}}(1-\mathrm{Pm})^{\mathrm{w}}}{\operatorname{Pon} \times \operatorname{Pn}^{\mathrm{r}}(1-\mathrm{Pn})^{\mathrm{w}}}
$$

In had three rules:

- Rule1: When the value of PR is bigger or equal to (1$\beta) / \alpha$, it means that student was mastery this part of concept.

- Rule2: While the value of PR is smaller to $\beta /(1-\alpha)$, it means that student was not mastery this part of concept.

- Rule3: The value of PR is between $(1-\beta) / \alpha$ and $\beta /(1-$ $\alpha)$, then student continue on test, when reach the end of the test then student was consider as partial mastery of this concept.

When use SPRT model we need to pay attention on two parts, First part is that question in the test must be random select and Second part is independence.

- Random select

When student was in the test, test questions must be unrepeatable and select from concepts.

- Independence

The score won't become difference by the order of the answer. Many experiment use the advantage of SPRT to test student's learning states such as:

1. Adapted learning by computerize teaching technology.[8]

2. Adapted testing by mastery of course testing.[9] 
3. The difficulty of questions didn't infect the learning measurement.[8]

4. Only mastery in the concept or not.[8]

\section{B. Confidence Indicator}

Because of the common use in learning by computer teaching, researchers think how to improve student's learning motivation, strengthening learning ability, make students to get self-management learning experience, so Gardner-Medwin build confidence indicator to measure the confidence of question that student choice[10], Table I shows the confidence indicator and figure 1 shows the score of expectation, research point out that when student use confidence indicator test, they can self-evaluate themselves and learning better, a research analyze learning type according to student's answer[4], it concluded two category :

1. Achievement - student who was driven by score, like to find the answer by themselves

2. Learning - student who needs feedback, they are willing to read and handle feedback, help them extend learning time.

\section{SEQUENTIAL PROBABILITY RATIO TEST+}

This SPRT+ algorithm is combine SPRT and confidence indicator, our course test is multiple-choice based, so we change the confidence indicator into Low $(0 \% \sim 33 \%)$, Middle (33\% 66\%), and High $(66 \% \sim 100 \%)$ three section, as figure 2 shows, according to this equation $\mathrm{y}-\mathrm{y} 1=\mathrm{m}(\mathrm{x}-\mathrm{x} 1)$ we can see the confidence student choice will influence their score.

Because of SPRT's variables are set at beginning, our study change this variables according to each student the figure 3 show the equation, when student choice confidence indicator and finish test, we can use this equation to find student's mastery of the concept.

\section{EXPERIMENTAL PROCEDURE}

Our study subjects are from Chung Yuan Christian University students who study Operating System, there are total 161 subjects, experimental group have 85 subjects, and control group have 76 subjects, student must finish SPRT + test and SPRT test then we compare both result with Pearson Correlation, first we use SPRT+ and SPRT to test student's learning efficiency, the result shows that SPRT + and SPRT have no Significant in the test, Table II shows both SPRT + and SPRT correctness about concepts.

In Table II, there is no such difference in both tests correctness, but Table III shows that SPRT+ use less question then SPRT, so our research use SPRT+ and using student's mid-term score as their confidence indicator to measure students learning efficiency to see SPRT + and SPRT + (pre-defined confidence indicator) both result can be the same or not.

In our experiment we use four concepts (Memory Management, Virtual Memory, File System, File System Structure) in Operation System to prove SPRT+ use less questions and measure student learning as SPRT did, then we use student's their own mid-term score as their confidence indicator and do SPRT+ test again the result was in Table IV compare with SPRT, we can see ConceptMemory Management shows that SPRT and SPRT+ test in this concept level are highly related. In Table V, Concept-Virtual Memory also shows in highly related. Concept-File System result is show in Table VI. Concept-File System Structure result in Table VII.

TABLE I.

CONFIDENCE INDICATOR [10]

\begin{tabular}{|c|c|c|c|c|}
\hline Confidence & $\mathbf{C = 1 ( l o w )}$ & $\mathbf{C = 2 ( m i d )}$ & $\mathbf{C = 3 ( h i g h )}$ & No Reply \\
\hline $\begin{array}{c}\text { Mark if } \\
\text { correct }\end{array}$ & 1 & 2 & 3 & $(0)$ \\
\hline $\begin{array}{c}\text { Penalty if } \\
\text { wrong }\end{array}$ & 0 & -2 & -6 & $(0)$ \\
\hline
\end{tabular}

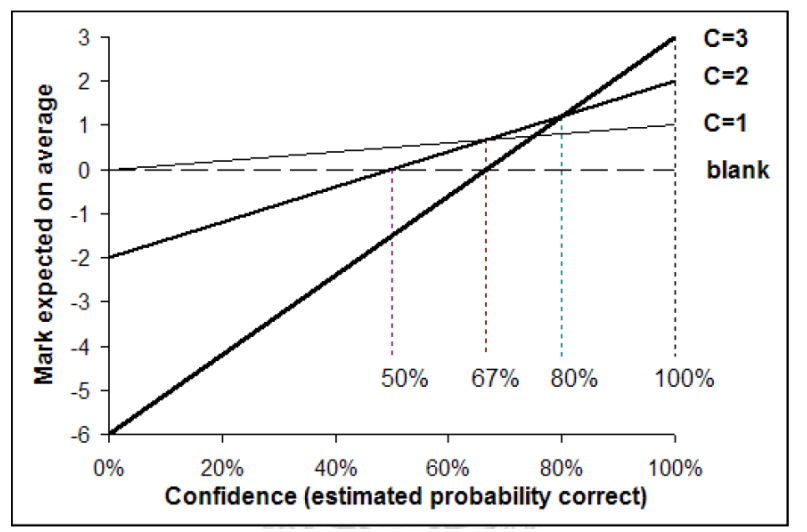

Figure 1. Score of expectation

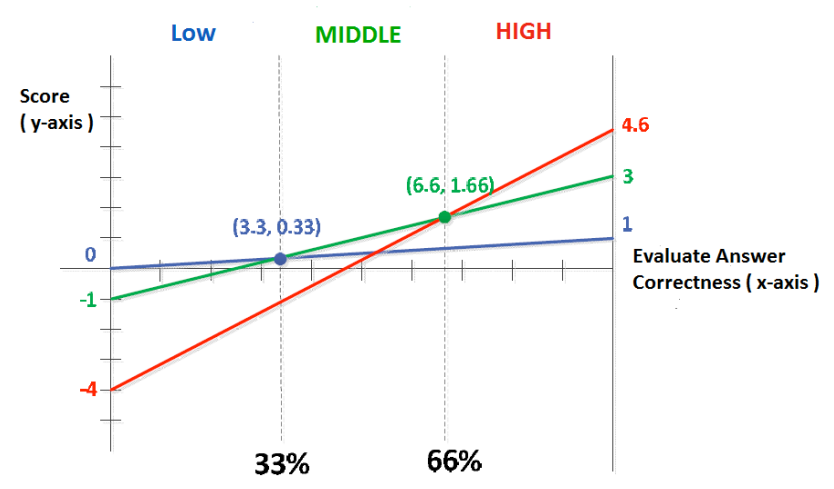

Figure 2. Score of expectation on SPRT+

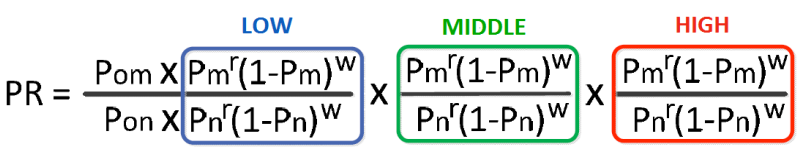

Figure 3. Equation of SPRT+

TABLE II.

ANSWER CORRECTNESS RATIO OF LEARNING STATE

\begin{tabular}{|c|c|c|c|c|c|}
\hline & $\begin{array}{c}\text { Learning } \\
\text { State }\end{array}$ & $\begin{array}{c}\text { Memory } \\
\text { Management }\end{array}$ & $\begin{array}{c}\text { Virtual } \\
\text { Memory }\end{array}$ & $\begin{array}{c}\text { File } \\
\text { System }\end{array}$ & $\begin{array}{c}\text { File System } \\
\text { Structure }\end{array}$ \\
\hline \multirow{3}{*}{ SPRT+ +} & Success & $91.11 \%$ & $92.68 \%$ & $82.22 \%$ & $90.23 \%$ \\
\cline { 2 - 6 } & Partial & $70.89 \%$ & $71.59 \%$ & $69.44 \%$ & $71.98 \%$ \\
\cline { 2 - 6 } & Fail & $51.13 \%$ & $41.71 \%$ & $48.14 \%$ & $48.03 \%$ \\
\hline \multirow{3}{*}{ SRPT } & Success & $90.72 \%$ & $90.59 \%$ & $82.14 \%$ & $91.67 \%$ \\
\cline { 2 - 6 } & Partial & $73.07 \%$ & $71.61 \%$ & $79.89 \%$ & $73.12 \%$ \\
\cline { 2 - 6 } & Fail & $51.95 \%$ & $42.25 \%$ & $49.15 \%$ & $48.71 \%$ \\
\hline
\end{tabular}


TABLE III. TABLE III AVERAGE NUMBER OF QUESTION IN CONCEPTS

\begin{tabular}{|c|c|c|c|c|c|}
\hline \multirow{4}{*}{ SPRT+ } & $\begin{array}{c}\text { Learning } \\
\text { State }\end{array}$ & $\begin{array}{c}\text { Memory } \\
\text { Management }\end{array}$ & $\begin{array}{c}\text { Virtual } \\
\text { Memory }\end{array}$ & $\begin{array}{c}\text { File } \\
\text { System }\end{array}$ & $\begin{array}{c}\text { File System } \\
\text { Structure }\end{array}$ \\
\cline { 2 - 6 } & Success & 7.50 & 7.45 & 15 & 11.08 \\
\cline { 2 - 6 } & Partial & 24.05 & 23 & 30 & 23 \\
\hline \multirow{3}{*}{ SPRT } & Fail & 10.16 & 7.82 & 9.97 & 9.64 \\
\cline { 2 - 6 } & Success & 13.86 & 14.17 & 28 & 13.33 \\
\cline { 2 - 6 } & Partial & 24.05 & 23 & 30 & 23.07 \\
\cline { 2 - 7 } & Fail & 11.55 & 8.31 & 10.54 & 10.42 \\
\hline
\end{tabular}

TABLE IV. TABLE IV PEARSON CORRELATION- MEMORY MANAGEMENT

\begin{tabular}{|c|c|c|c|}
\hline & & $\begin{array}{c}\text { SPRT Con- } \\
\text { cept Level }\end{array}$ & $\begin{array}{c}\text { SPRT+ Con- } \\
\text { cept Level }\end{array}$ \\
\hline \multirow{2}{*}{$\begin{array}{c}\text { SPRT } \\
\text { Concept } \\
\text { Level }\end{array}$} & $\begin{array}{c}\text { Pearson Corre- } \\
\text { lation }\end{array}$ & 1 & $.833^{* *}$ \\
\cline { 2 - 4 } & Sig. (two-tailed) & & .000 \\
\cline { 2 - 4 } & $\mathbf{N}$ & 117 & 117 \\
\hline \multirow{2}{\text{SPRT+}}{$\begin{array}{c}\text { Concept } \\
\text { Level }\end{array}$} & $\begin{array}{c}\text { Pearson Corre- } \\
\text { lation }\end{array}$ & $.833^{* *}$ & 1 \\
\cline { 2 - 4 } & Sig. (two-tailed) & .000 & 117 \\
\cline { 2 - 4 } & $\mathbf{N}$ & 117 & \\
\hline
\end{tabular}

TABLE V. TABLE V PEARSON CORRELATION-VIRTUAL MEMORY

\begin{tabular}{|c|c|c|c|}
\hline & & $\begin{array}{c}\text { SPRT Con- } \\
\text { cept Level }\end{array}$ & $\begin{array}{c}\text { SPRT+ Con- } \\
\text { cept Level }\end{array}$ \\
\hline \multirow{2}{*}{$\begin{array}{c}\text { SPRT } \\
\text { Concept } \\
\text { Level }\end{array}$} & $\begin{array}{c}\text { Pearson Corre- } \\
\text { lation }\end{array}$ & 1 & $.771^{* *}$ \\
\cline { 2 - 4 } & Sig. (two-tailed) & & .000 \\
\cline { 2 - 4 } & $\mathbf{N}$ & 117 & 117 \\
\hline \multirow{2}{\text{SPRT+}}{$\begin{array}{c}\text { Concept } \\
\text { Level }\end{array}$} & $\begin{array}{c}\text { Pearson Corre- } \\
\text { lation }\end{array}$ & $.771^{* *}$ & 1 \\
\cline { 2 - 4 } & Sig. (two-tailed) & .000 & 117 \\
\cline { 2 - 4 } & $\mathbf{N}$ & 117 & \\
\hline
\end{tabular}

TABLE VI. TABLE VI PEARSON CORRELATION- FILE SySTEM

\begin{tabular}{|c|c|c|c|}
\hline & & $\begin{array}{c}\text { SPRT Con- } \\
\text { cept Level }\end{array}$ & $\begin{array}{c}\text { SPRT+ Con- } \\
\text { cept Level }\end{array}$ \\
\hline \multirow{2}{*}{$\begin{array}{c}\text { SPRT } \\
\text { Concept } \\
\text { Level }\end{array}$} & $\begin{array}{c}\text { Pearson Corre- } \\
\text { lation }\end{array}$ & 1 & $.791^{* *}$ \\
\cline { 2 - 4 } & Sig. (two-tailed) & & .000 \\
\cline { 2 - 4 } & $\mathbf{N}$ & 117 & 117 \\
\hline \multirow{2}{*}{$\begin{array}{c}\text { SPRT+ } \\
\text { Concept } \\
\text { Level }\end{array}$} & $\begin{array}{c}\text { Pearson Corre- } \\
\text { lation }\end{array}$ & $.791^{* *}$ & 1 \\
\cline { 2 - 4 } & Sig. (two-tailed) & .000 & 117 \\
\cline { 2 - 4 } & $\mathbf{N}$ & 117 & \\
\hline
\end{tabular}

TABLE VII. TABLE VII PEARSON CORRELATION- FILE SySTEM STRUCTURE

\begin{tabular}{|c|c|c|c|}
\hline & & $\begin{array}{c}\text { SPRT Con- } \\
\text { cept Level }\end{array}$ & $\begin{array}{c}\text { SPRT+ Con- } \\
\text { cept Level }\end{array}$ \\
\hline \multirow{2}{*}{$\begin{array}{c}\text { SPRT } \\
\text { Concept } \\
\text { Level }\end{array}$} & $\begin{array}{c}\text { Pearson Corre- } \\
\text { lation }\end{array}$ & 1 & $.806^{* *}$ \\
\cline { 2 - 4 } & Sig. (two-tailed) & & .000 \\
\cline { 2 - 4 } & $\mathbf{N}$ & 117 & 117 \\
\hline \multirow{2}{\text{SPRT+}}{$\begin{array}{c}\text { Concept } \\
\text { Level }\end{array}$} & $\begin{array}{c}\text { Pearson Corre- } \\
\text { lation }\end{array}$ & $.806^{* *}$ & 1 \\
\cline { 2 - 4 } & Sig. (two-tailed) & .000 & \\
\cline { 2 - 4 } & $\mathbf{N}$ & 117 & 117 \\
\hline
\end{tabular}

\section{DISCUSSION}

Each student have to complete three tests, SPRT, SPRT + and SPRT+ with pre-defined confidence indicator, the result shows that each concept has highly related with SPRT, when we let student to choice their own confidence indicator in the SPRT+ test, the result shows that there are no difference in SPRT, if we set student's confidence indicator the result is just like SPRT+ test which student choice their confidence, so our study use SPRT+ (predefined confidence indicator) test and find out that the test time was reduce and also measure student efficiency like SPRT+ did.

When we use this algorithm, we can pre-define student's confidence about each concept, because mid-term exam can show a student's learning progress, so we can know their learning state, and use it to reduce measure time.

Our study focus on reduce measure time by using SPRT + and pre-defined student's confidence indicator in every concepts and measure student's learning efficiency precisely, in our result in Table III shows SPRT+ using less question to measure student's learning state, this means that test time was been reduce beside this we predefined student's confidence indicator, so student just need to focus on answer the question, so test time was been reduce again, and the test result was show in Table IV to Table VII is highly related to SPRT, so using this method we can measure student's learning efficiency with less time that won't make student feel tired and make us hard to measure their learning efficiency, this method can widely use in many course which can divide into concepts because it's high efficiency and accurate as SPRT.

\section{REFERENCES}

[1] Ling-Hsiu Chen (2010). Web-based learning programs: Use by learners with various cognitive styles.Computers \& Education. http://dx.doi.org/10.1016/j.compedu.2009.10.008

[2] Roman Taraban, Alli Difinis, Ashlee G. Brown, Edward E. Anderson and M. P. Sharma (2007). A Paradigm for Assessing Conceptual andProcedural Knowledge in Engineering Students. Journal of Engineering EducationOctober 2007.

[3] Chih-Ming Chen, Ying-Ling Hsieh and Shih-Hsun Hsu(2007).Mining learner profile utilizing association rule for web-basedlearning diagnosis.Expert Systems with Applications 33.

[4] Ingrid Nix and Ali Wyllie(2011). Exploring design features to enhance computer-based assessment: Learners' views on using a confidenceindicator tool and computer-based feedback. British Journal of Educational Technology Vol 42 No1 2011. http://dx.doi.org/10.1111/j.1467-8535.2009.00992.x

[5] Kathleen Scalise and Bernard Gifford (2006). Computer-Based Assessment in E-Learning:A Framework for Constructing "Intermediate Constraint"Questions and Tasks for Technology Platforms. The Journal of Technology Learning and AssessmentVolume 4.

[6] Hans J. Vos and Cees A. W. Glas (2010).Testlet-Based Adaptive Mastery Testing.Statistics for Social and Behavioral Sciences, Part 5, 389-407.

[7] Abraham Wald (1947). Sequential Analysis. New York: John Wiley and Sons.

[8] Theodore W. Frick (1989). Bayesian Adaptation During Computer-Based Tests and Computer-Guided Practice Exercises. Journal of Educational Computing Research Volume 5.

[9] David J. Weiss, G. Gage Kingsbury(1984), Application of Computerized Adaptive Testing to Educational Problems, Journal of Educational Measurement. http://dx.doi.org/10.1111/j.17453984.1984.tb01040.x

[10] Gardner-Medwin AR(1995). Confidence Assessment in the Teaching of Basic Science. Association for Learning Technology Journal3,80-85. http://dx.doi.org/10.1080/0968776950030113 


\section{AUTHORS}

A. Chien-Hung Lai received the B.S. and the M.S. degree in Department of Information and Computer Engineering from Chung Yuan Christian University, Taoyuan, Taiwan in 2008 and 2010. He is now a Ph.D. candidate in Department of Electronic Engineering at Chung Yuan Christian University, Taoyuan, Taiwan. His research interests include computer aided education.

B. Tsung-Po Lee is with the Department of Information and Computer Engineering, Chung Yuan Christian University, Taoyuan, Taiwan. (e-mail: robertfly02@hotmail.com)

C. Bin-Shyan Jong received the B.S. degree in Department of Electronic Engineering from Chung Yuan Christian University in 1978, and the M.S. and Ph.D. degree from the Institute of Computer Science in 1983 and
1989 at National Tsing Hua University, Hsinchu, Taiwan. $\mathrm{He}$ is a professor in the Department of Information and Computer Engineering, Chung Yuan Christian University. His research interests include computer graphics and computer aided education.

D. Yen-Teh Hsia received the B.S. degree in Department of Navigation Technology and Marine Engineering from National Chiao Tung University, Hsiuchu, Taiwan in 1978, and the M.S and Ph.D. degree from the Department of Computer Science at University of Kansas in 1986 and 1989. He is now an associate professor in the Department of Information and Computer Engineering, Chung Yuan Christian University. His research interests include computer aided education and artificial intelligence.

Submitted 06 November 2013. Published as re-submitted by the authors 18 May 2014. 